\title{
Artelogie
}

Recherche sur les arts, le patrimoine et la littérature de l'Amérique latine

$7 \mid 2015$

Photographie contemporaine en Amérique latine

\section{Translation Betrayals: The Photographs of El 10 de Febrero}

Juanita Solano Roa

(2) OpenEdition

Journals

Electronic version

URL: https://journals.openedition.org/artelogie/1084

DOI: 10.4000/artelogie.1084

ISSN: 2115-6395

\section{Publisher}

Association ESCAL

Electronic reference

Juanita Solano Roa, "Translation Betrayals: The Photographs of El 10 de Febrero", Artelogie [Online], 7| 2015, Online since 15 April 2015, connection on 11 April 2022. URL: http://journals.openedition.org/ artelogie/1084 ; DOI: https://doi.org/10.4000/artelogie.1084

This text was automatically generated on 11 April 2022

Association ESCAL 


\title{
Translation Betrayals: The Photographs of El 10 de Febrero
}

\author{
Juanita Solano Roa
}

\begin{abstract}
"Warning. This book is edited with permission of Colombia's government and the documents that appear here are taken from the corresponding Ministry of War files." (ANONYMOUS, 1907 : p.3)
\end{abstract}

1 With this note opens the anonymous book El 10 de Febrero printed in New York in 1907 and distributed across Colombia during that same year. The book compiled the documentation of the attempted assassination of Colombia's current president Rafael Reyes and the subsequent public execution by firing squad of the conspirators, which took place a year before the book was published. El 10 de Febrero includes a narrative account of the murder attempt and documents evidencing the horror of the crime, including a series of photographs that spark interesting debates. The argument that follows will look at part of this visual documentation as an opportunity to examine the role of the medium of photography as a form of visual translation and the subsequent difficulty of such an understanding.

Three men on horses wearing ruanas and hats are sitting on horses in front of a local bar while a standing man offers one of them a bottle of liquor (brandy, we know, after reading the caption). The four men are all looking backwards, hence none of their faces are portrayed in the image, and the interaction between the man that stands and the one that receives the bottle is rather awkward. They are not looking at each other and instead they both face the wall [Fig. 2]. Indeed, this image is part of a larger series of doctored photographs taken in 1906 by Colombian photographer Lino Lara, who was presumably commissioned by the police to produce photographic reconstructions of the president's attempted murder. Lara's final work includes the photograph described above and continues with thirteen additional images that narrate the story, first as a horrifying crime and then as a heroic quest with the valiant capturing of the criminals [Figs. 1-15]. It is known through previous research that the first two parts of the series are staged. However, in the publication such a statement was not included and the 
images appeared together with a third and final group of photographs, which depict the execution of the delinquents [Figs. 16-20]. It is important to highlight that these last photographs do accurately document an event; an execution in fact that did occur as shown by the images.

El 10 de Febrero thus presents a case study critical to the understanding of photography as an accurate visual translation of real events because the book, self-reflexively, problematizes this notion. Photographic imagery is paradoxical : on the one hand is it arguably the most accurate visual translation that exists and on the other photography is incredibly open to interpretation. In Barthes's terms, photography can only say "this-has-been." (BARTHES, $2010:$ p.79) The reading of a photograph is determined by its context and in many cases-including this one-text plays a seminal role in determining the meaning of the images. In El 10 de Febrero, all the pictures have captions that direct the reading of the photographs.

4 Translation is a process that aims to transmit an idea from a specific language into another, without changing the original idea. It can change its form but not its meaning. With photography, however, we are confronted with a process that does not aim to make the source language (i.e. reality/the referent) understandable in a different one (i.e. photography). It is a translation that aims at making visible and reproducible the source language. In other words, we are confronted with a literal, yet not faithful, translation. Translation in photography is betrayal. It can be understood as a word-byword translation that does not necessarily convey the original meaning. This might be the case because the world does not have a grammar of its own and therefore any translation is weak in signification. The problem with photography is even more complex due to its faithful iconicity and capacity for mimesis. Therefore, the translation process, evident in other media such as drawing or painting, becomes confused with photography, thus allowing for the possibility of deceiving the spectator.

With $\mathrm{El} 10$ de Febrero the observer is confronted with a seemingly seamless collusion of reality and fiction due to photography's indexical properties. Unlike other systems of representation, photography gravitates between the three main types of signs in a rather complex way. Charles S. Pierce identified them in relation to their referents : icons, symbols and indexes. Icons are signs that are unrelated to their referents; in other words they are autonomous but maintain a resemblance and a reference relationship with the object they represent. There are three different types of icons : images-such as paintings and drawings-diagrams and metaphors. Symbols, on the other hand, are signs characterized by recalling other objects ; they are conventional, general and arbitrary. The most obvious examples are words or traffic signs. And lastly, indexes are signs that maintain a real connection with their referent. They are governed by the principle of existential union, i.e. there is a physical link between an index and its referent. Indexes do not signify anything by themselves because they are completely dependent on their referent. Some examples are fingerprints, traces, smoke and, of course, photography (DUBOIS, $1986:$ p.57-60). It is due to that "necessarily real thing" standing in front of the camera (that is, the photographic referent) that photographs can count as legal evidence and it is because of this very unique condition of icons and indexes that it is so important that the images in $E l 10$ de Febrero are photographs and not drawings or paintings. A drawing of a criminal shooting the president would count more as an interpretation of the event rather than as evidence of its truth, which was ultimately what the author of the book was really looking to 
accomplish. The reality of the reference, i.e. the criminal shooting, would be optional in a drawing, whereas in the photograph it is necessary (BENN MICHAELS, 2007 : p.344). However, photography's indexicality makes it difficult to see these images as pictures, as representations, and it allows for a space of artificial performance, of theatricality, that can easily be hidden within the image.

El 10 de Febrero poses a complex case, further complicated by the notion of truth and therefore, at the same time, the idea of accurate translation in photography. The staged photographs, those that depict the murder attempt, could be understood as a double translation. The people portrayed in the images were police members enlisted to act out the roles of the criminals. The national police chief Pedro A. Pedraza, a photographer himself, hired Lara, a photographer recognized for his interest in documenting the most scandalous events in Bogotá (SERRANO, 1983 : p.175). Lara had previously documented the fire of the emblematic building Las Galerías de Arrubla in 1900 and scenes of the recruitment of men for the war (SERRANO, 1983 : p.175). Lara's fabricated photographs created a two-sided translation, from the historical event (its presentation) to a mise-en-scène (its representation), and from the mise-en-scène to the photographic images (its double re-presentation). What constitutes, however, the breaking point of the series is their juxtaposition with the non-doctored images of the execution.

7 After the capture of the criminals and their confession to plotting to kill the president, an ad hoc tribunal ordered the summary execution of the delinquents by firing squad. This was arguably the president's most severe act during his dictatorship. ${ }^{1}$ The death penalty was still debated in the country and the majority of the population was against it. Indeed, in 1910 the capital punishment was abolished in Colombia. The execution was a grand spectacle for Bogotá's inhabitants; more than 10,000 people came to see the event. Lara's photographs so vividly recall these moments in history that the doctored images were invested with that same sensation of reality. In other words, the documentation of the execution was so real, that the fiction of the previous photographs faded away anchoring the fake pictures both ontologically and symbolically. This idea of the real in the doctored photographs is further reinforced by the images' aesthetic. The photographs give the sensation of having been taken in the moment of the action due to their blurriness and distance from their referent. Take, for example, the first image of the series, which depicts the moment in which two of the conspirators attacked the president and his daughter. The picture is precisely composed in order to include all the characters playing their role in the scene. The action was restaged exactly at the same place where the actual event took place and the photographic depiction transmits the bewilderment of the scene: the scared carriage horses, the smoke coming out from the carriage, the criminals shooting their guns and the general blurriness of the image [Fig. 1]. Indeed, images of horror or tragedy seem more real when they are not well composed or properly lit. There is a deliberate amateurish aesthetic invested in the photographs of the first part of El 10 de Febrero, distinguished from those of the second part, which are more clear and detailed. As noted by Susan Sontag, "[b]y flying low, artistically speaking, such pictures are thought to be less manipulative (...) and less likely to arouse facile compassion or identification" (SONTAG, $2004:$ p.23).

8 As stated before, El 10 de Febrero not only comprised the photographic images, it also included a narrative description of the murder attempt possibly written by the 
reporter Alberto Calderón, followed by a transcription of the president's diary with the details of the event and a compilation of the declarations given by a few testimonies, including statements of Juan Ortiz, one of the criminals. In his last declaration Ortiz confessed the details of the plot to murder Reyes and to position a group of radical conservators in power. Ortiz's story is read as a novel, as a non-fiction account in which the characters of the story narrate in their own voice the events as happened in real life. The book continues with a chapter that includes the police report which states how the criminals were captured, the declarations of each of the three miscreants, condolence notes addressed to the president and a transcription of the notes of a reporter taken the day of the murder attempt which were published in El Correo Nacional, the local newspaper (HOYOS, 2009: p.57-59). The inclusion of the photographs in the book was a deliberate attempt at reinforcing the documentary character of the publication. In this case the images worked as a "conduit and agent of ideology, purveyor of empirical evidence and visual "truths." (SOLOMON-GODEAU, 1991: p. 170)

9 As John Tagg has extensively argued the problem with the "documentary" relied not only in the photograph's apparent transparency but also in "the institutions, discourses, and systems of power that invest it and sully it, and via the discourse regimen that constitutes the document and holist in its place." (TAGG, 1988: p. XXI) Indeed, El 10 de Febrero was a biased document carefully arranged within the rhetoric of power imposed by the police and ultimately by the government itself. The use of photography as a tool for denunciation and control in Colombia was new, in particular, its use for publication and circulation. Around the same time when the execution photos by Lara were taken, Benjamin de la Calle, a photographer active in Medellin, documented the last execution in the country. His images are closer to the type of police documentation used for surveillance and control used today. De la Calle's photos do not depict the action of the execution, as Lara's photographs do, but the aftermath of the brutal action in a frontal, sharp and more "objective" way. This approach allows the discourse in Lara's photographs to be clearer: the images delivered the sense of transparency and evidence carefully orchestrated by the author of the book as a power strategy. In order to reconstruct the crime scene, Lara appeared to be following the later standard reference on photographic evidence written by S.G. Ehrlich in the 1960s, a fellow of the Royal Microscopical Society and member of The American Society of Photographic Scientists and Engineers. In the document Ehrlich stated that: “(...) the good photographer must have the imagination and creative ability to reproduce scenes on films so that they will convey to the viewer the same information and impressions he would have received had he directly observed the scene." (TAGG, 1988: p. 97)

10 El 10 de Febrero is certainly not the first example of doctored photography used to convey a "politically tendentious" version of a historical event, but it is certainly one of the few that so seamlessly conflated documentary and fictive images at such an early stage. A similar example of doctored photography-which curiously seems to be also the first of its kind-is a series of photo-collages created by the French portraitist Ernest Eugène Appert in 1871. Based on reports of the revolts that took place in Versailles after the fall of Napoleon III and the end of the Franco-Prussian war, Appert created Crimes de la Commune, a series of nine photo-collages, which depict scenes from the insurrection [Fig. 21-22]. He fabricated the images by using his own photo-archive and by hiring professional actors who restaged the events in his studio. Cutting and pasting the photographs he took of the actors onto photographic backgrounds of the places where the actions really took place, Appert created the final compositions. He 
also added headshots of the key commune participants in order to insert a sense of reality into the final images, which were ultimately re-photographed and reproduced in different sizes and formats (FINEMAN, 2012 : p.93-94).

11 It seems unlikely that the Appert's images could have been read as fake, nor does this reaction seems feasible with regards to the photos of $E l 10$ de Febrero. Appert's images were too small and relatively well constructed and Lara's pictures were invested with a high sense of the real. Additionally, the general public was not knowledgeable of photographic techniques. However, both cases do bring up the concern of using photography as a tool for political propaganda. As stated by Sontag, events "become real by being photographed" and "when it comes to remembering the photograph has a deeper bite" (SONTAG, 2004: p.19). The fabrication of the photographs of El 10 de Febrero can be understood as the antonym of iconoclasm. Whereas in iconoclasm the object is confronted with destruction, or as Hans Belting put it, is "prohibited from taking material form in an effort to protect people from what they are false image," (BELTING, 2011 : p.11) in El 10 de febrero, the reconstruction of the event as photographs "consecrates [the] pictures to work," materializing history and endowing them with power.

12 It is not a coincidence that the first photograph that appears in $\mathrm{El} 10$ de Febrero is the photograph of the shooting-the decisive moment of the series-when the criminals are firing the president. The photographic series then flashes back and starts the story from the beginning, when the criminals are waiting for the president's carriage to pass by. When the moment of the shooting appears again in the story, this time in the linear account, the image utilized is similar to the one shown at the beginning of the book. It depicts one of the criminals on a horse shooting his gun to the back of the carriage, while the driver has gotten up and turned backwards, firing his gun at the criminals at the same time [Fig. 5]. At a first glance the two images seem to be taken at the same time from different perspectives by two different persons. However, this seems unlikely considering the difficulty of working with photography at this time in Colombia; cameras were still big and heavy, and the photographers' profession was not based on teamwork. Additionally, the impossibility of such a task is reinforced by the inaccuracy of the position of the criminal shooting the carriage when the two photographs are compared. In the first photograph the delinquent is shooting towards the front of the carriage whereas in the second he is shooting to its back. The discrepancy between these two photographs-which are supposedly two different shots of the same moment-means that the re-enactment must have taken place several times in order to produce all the images included in the book and it sparks the question of how public the re-enactment itself was.

13 Perhaps the most interesting comparison between these two photographs is not visual but verbal, in other words, the captions of the pictures. The first image is accompanied by a text that reads: "Assault on Mr. President and his daughter in "Barrocolorado"' and the second text states "Attack on Mr. President-Captain Pomar shoots his gun." By changing the agency of the shooter-in the first case the criminal and in the second Pomar, i.e. the president's driver-through the textual information, the image acquires a different meaning. At a first glance one might think that the text could be interchangeable between the two images, but it is not, because the later photograph shows a second person shooting his gun, the driver, indeed, who does not appear in the first image. It is remarkable to note that this small, though important detail of the 
photograph does not become evident until the caption is read. Pomar is almost unnoticeable in the picture for he stands in the middle ground of the image nearly blurred by the landscape in the back and the attention of the picture is directed at the criminal shooting from the left. This example shows how important the textual supplement of the image was and it reinforces the fact that photography is a visual translation that lacks a meaning in its own. Following Umberco Eco's ideas, a good translation is that which is not concerned with denoting but with connoting, and this strengthens Roland Barthes's repeated idea that photography, as a message without a code, cannot convey a single meaning (ECO, $2001:$ p.8).

As Barthes has explored in depth, images have a certain rhetoric and photography's ability to mimetically translate the real is perhaps both its biggest advantage and biggest disadvantage since the "image is weak in respect to meaning" (BARTHES, 1980: p.269). The image is its own limit. The meaning of the photograph is dependent on a supplement, in this case, a series of supplements: the text that comes in the book, the captions of each image, and, most importantly, the relation between the fake and the real photographs. In other words, the spectator is confronted with an unreadable translation that only acquires meaning when it is supported by something else.

The president, who seems to be the author of the book, delineated the rhetoric of the images in El 10 de Febrero. Taking into account the quality of the book and its presumably high cost of printing (since it was produced in New York), who but the government would have been able to afford for such an edition and have access to all these documents? The book is today read as part of Reyes's political agenda; it served as a way to justify the decision of imposing the death penalty on the criminals and the best way to do so was by demonstrating the horror of the crime committed against Reyes. The captions of the images do not seem to be created a priori in order to dictate the construction of the doctored photographs; the texts are too general and therefore many types of photographs could have been created following the statements that came with the images. For example, one of the photographs is accompanied by a text that reads "The three assailants fleeing along the north road." The image, however, barely shows the criminals (they are only visible when enlarging the image; something that a regular reader would never do) and the photograph rather represents a desolated landscape of an unpaved road with a cow and a house standing on the left side [Fig. 7]. This evidences how the text was imposed to the images after they were fabricated, anchoring the photographs to a system of signification.

The type of language utilized in the captions speaks to the intentionality of the photographs. The doctored pictures come with active phrases, which clearly indicate the subject, and therefore, the person executing the action, which is, in almost all the cases (besides the one in which the president's driver is shooting the gun), one of the criminals. In the last part of the series, the non-doctored photographs appear together with either captions written in passive form-such as "The criminals were passed into death by the guns" or "The cadavers are taken to the cemetery"-or phrases that do not even contain a verb or a subject as, for example, in a text that reads "After the shooting." In this way, the agency of the criminals is reinforced in the doctored pictures, while that of government is avoided in the images that touch directly on the sensitive subject of the public execution. Even though the photographs clearly evidence that the policemen were shooting, not once, but twice, the caption annuls their responsibility in the action of killing. 

because it cannot be faked, and yet, it seems to be $E l 10$ de Febrero's main subject: the book starts with an attempt at death and ends with death itself. As Barthes continuously reminds us in his book Camera Lucida, death is the eidos of photography. Indeed, death is so present in the photographs of $E l 10$ de Febrero that, I argue, one can speak about a triple sense of death in this series: first, the one the subjects experience at the moment Lino Lara shot them with his camera (Barthes speaks about a sense of death when one is being photographed, since, for a instant, the subject becomes an object. He stated: "I am neither subject or object but a subject who feels he is becoming an object: I then experience a micro version of death (of parenthesis): I am truly becoming a specter.") (BARTHES, 2014: p.14); the imminent condition of photography of becoming history, of being always part of the past and therefore always acknowledging its subjects' future death; and last, the actual death of the criminals, the execution.

Barthes saw death in the future when looking at a photograph of Lewis Payne-a conspirator in the Lincoln assassination-taken by Alexander Gardner in 1865 just before Payne's execution. This time, Barthes did not only see the past, as he usually saw in photography, but he also saw the future: Payne was going to die (BARTHES, 2014: $\mathrm{p}$. 14). Contrary to what Barthes saw in the photo of Lewis Payne, the photos in $E l 10$ de Febrero do not tell that "[they are] going to die." The photographs don't tell the future death of the criminals, as Barthes saw in Gardner's image, they instead embody it. In Lara's execution photographs time is collapsed. They are the present and the past conflated and there is no future to look forward to. Death is the end of photographic representation and therefore also the end of photographic translation.

El 10 de Febrero photographs are divided into two ontologically different types of photography. The doctored images, which point to a fictional sphere and a fake attempt at death, and the real photographs, which direct the viewer to a documentary domain, with the real death of the criminals. Although the book was intentionally created to produce a higher degree of affect towards the attempted assassination of the president, the photographs of the execution are still more disturbing. This is so because while inserted in the book, these images break with the possibility of considering the first group a set of doctored images. In other words, they seem to disrupt any possibility of fiction. The images that captured the experience of the execution embody a collective memory that is transferred to the doctored pictures, transforming what was possibly fictional into documentary. They translate a symbolic meaning into indexical representation. Perhaps, as Vivian Sobchack notes,

the carve of the real that moves us from fictional into documentary consciousness is always more than a generalized existential information of the image of the mere "response-ability" of our actual bodies. The charge of the real always is also, if to varying degree, an ethical charge: one that calls forth not only response but also responsibility-not only aesthetic valuation but also ethical judgment. It engages our awareness not only of the existential consequences of representation but also of our own ethical implication in representation (SNOBCHACK, 2004: p.284).

21 The relationship between the representations of death in photography and in cinema is an interesting one to consider in this paper, since the photographs of $\mathrm{El} 10$ de Febrero allude to a cinematographic discourse through their narrative format. Indeed, it has been suggested that the idea of creating a sequence of photos might have derived from 
cinema, since the first projections of movies had recently taken place in Bogota in 1897. However, the images of the book are photographs, and this fact is very important for the consideration of death as their subject. When one approaches a photo of a dead person, one experiences melancholy remembering the depicted character. On the contrary, in cinema, when one sees a movie and a character dies or is killed (even if the actor is already dead), the spectator doesn't think about him/her with melancholy because cinematographic fiction exceeds reality. The acting nullifies identity in cinema whereas in photography it does not; the subject is always present.

In 1840, Hippolyte Bayard created Self-Portrait as a Drowned Man, a photograph where he presented himself as a victim of suicide, due to his anger over the unwillingness of the French government to recognize his invention of a photographic process as equal to that of Daguerre. The photograph was signed and accompanied by a "suicide" note on the back explaining the reason of his death. This image, created at photography's invention, displays the problems of representation and death as the focus of this photographic problematic. As stated by scholar Micha Sapir, "it play[ed] on the tension between the notion of death and visualization as means of authentication, and the inauthenticity inherent in the act of making death visible" (SAPIR, 1994: 620). Death, as critic Amos Vogel suggests, possesses a "ferocious reality" that exceeds attempts to represent it or culturally contain it (SOBCHACK, 2004: p.226). It can be argued that Colombia's president, Rafael Reyes, was utilizing a similar strategy of authentication by, on the one hand, making his attempted assassination public-visible and reproducible-and on the other, leaving a document that negated the reality of this fact. In the same manner that Bayard's photograph simultaneously documents and questions photographic truth, El 10 de Febrero has been considered the first large photographic documentary record of a historical event in Colombia, and yet, a large part of its visual "evidence" is fictional.

The last part of the $E l 10$ de Febrero series is comprised by fewer images than the first part; only five photographs appear in this later section. The photographs focus on the spectacle of the execution and not solely on the criminals (MINISTERIO DE CULTURA, 2000: p.56). This is evidenced by the use of general shots as seen in the first and the last photographs of this part of the series. The first depicts an overview of the delinquents sitting along with other condemns before the execution [Fig. 16]. Almost all of them turn their gaze away from the camera, from the public scorn, hiding their faces behind the hats that many are wearing. Only the policeman on the right of the photograph directs his view towards the photographer or, perhaps, the general public. The last image reinforces the spectacle. It shows the moment when the cadavers are being taken to the cemetery [Fig. 20]. Again, the photographer opted for a general view that shows the large amount of people that came to see the event, and deliberately evades the inclusion of any image that could evoke the citizens' rejection against the execution.

Ultimately, the issue with the representation of death is that it is a presentation, not a re-presentation. It is the depiction of a state that cannot be experienced a priori and thus its representation is ambiguous. And yet, it is the one condition that every living being will experience. The depiction of the corpse itself does not represent death because it does not create affect. What moves and touches emotion is what the body signified, and that meaning is given by what the body did, as a living person. It is for this reason that the government had to create the doctored photographs. They had to invest the 
corpses of the execution photographs with meaning, and, most importantly, with affect in order to justify their controversial decision.

The ethics of photography play an important role in this series of photographs. As Joan Fontcuberta has noted every photograph is a fiction that presents itself as truth and the importance relies on how the images are used and what intentions they serve because photography, for him, always lies. In his words: "The importance, ultimately, is the control employed by the photographer in order to impose an ethic direction to his lie. The good photographer is that who uses well a lie to tell the truth." (FONTCUBERTA, 1997: p.15) In El 10 de Febrero, however, the ethics are questionable, since it is the powerful institution the one that imposes the meaning to the photographs and there is no other documentation to counterbalance that perspective. The photographs were created with the clear intention of supporting the president's account and at a first glance they seemed to do so. Yet, when looked and analyzed closely the mise-en-scène is unveiled.

In conclusion, the photographs of El 10 de Febrero simultaneously embody and question the essence of photography. The series not only sparks questions of the accurate or inaccurate translation from the real world into photographic representation, it also brings up the problems of a translation between the fictive and the documentary status of the image within photography itself, a translation generated by the context and seamless conflation of the images. To summarize, in El 10 de Febrero three different cases of translation appear: first, the simple visual translation between the real world and its mimetic representation, i.e. photography (though two-dimensional, significantly smaller, in black and white, and cut out of from its context); second, the translation between the historical event and its mise-en-scène; and third, the translation of the fictional photographs into documentary evidence. This series reaffirms and negates the essence of photography at the same time, therefore becoming a unique example in the history of this medium that helps us understand it from a critical standpoint. Addressing these photographs as a form of translation allows us to interrogate the nature of the images and their function as documents in a larger political agenda.

\section{BIBLIOGRAPHY}

BARTHES Roland, “The discourse of History.”, in Structuralism : A Reader, edited by Michael Lane. London, Cape, 1970.

BARTHES Roland, “The Rhetoric of the Image.”, in Classic Essays on Photography, edited by Alan Trachtenberg, 269-285. New Heaven, Leete's Island Books, 1980.

BARTHES Roland, Camera Lucida: Reflections on Photography, New York, Hill and Wang, 2010. BELTING Hans, An Anthropology of Images: Picture, Medium, Body. Princeton, Princeton University Press, 2011. 
CRARY Jonathan, "Modernizing Vision.", in Vision and Visuality, edited by Hal Foster, pages. Seattle, Bay Press, 1988.

CRARY Jonathan, Techniques of the Observer, Cambridge, Massachusetts, MIT Press, 1992.

DUBOI Philippe, El acto fotográfico, Barcelona, Paidós Ibérica, 1986.

Eco Umberto, Experiences in Translatio, Toronto and Buffalo, University of Toronto Press, 2001.

El Diez de Febrero, New York, Imprenta Hispano-Americana, 1907.

FINEMAN Mia, Faking it, New York, Metropolitan Museum of Art, distributed by Yale University

Press, 2012.

FONTCUBERTA Joan, El beso de Judas: Fotografía y verdad, Barcelona, Gustavo Gili, 1997.

HoYos Juan José, La Pasión por contar. El periodismo narrativo en Colombia 1638-2000. Medellín :

Universidad de Antioquia, 2009.

KÖHLER Michael, Constructed realities. The Art of Staged Photography, Switzerland, Edition Stemmle, 1995.

KRAUSS Rosalind, "Notes on the Index: Seventies Art in America. Part 2", in October 4 (Autumn 1977): 58-67.

KRAUSS Rosalind, "Notes on the Index: Seventies Art in America", in October 3, (Spring,1977) : 68-81.

MICHAELS Walter Benn, "Photography and Fossils.", in Photography Theory, edited by James Elkins, 431-450. London, Routledge, 2007.

Ministerio de Cultura, Proyecto Pentágono: investigaciones sobre arte contemporáneo en Colombia, Santafé de Bogotá, Ministerio de Cultura, 2000.

ORVELl Miles, American Photography, New York, Oxford University Press, 2003.

ORVELL Miles, The Real Thing: Imitation and authenticity in American Culture; Chapel Hill, University of North Carolina Press, 1989.

ROJAS Sotelo Miguel, et al. Proyecto Pentágono: Investigaciones sobre Arte Contemporáneo en Colombia, Bogotá, Ministerio de Cultura, 2000.

RUBIANO Juan Carlos, RUBIANO VARGAS Roberto and RODA Marcos, Crónica de la fotografía en Colombia, 1841 - 1948, Taller La Huella, Carlos Valencia Editores.

SALCEDo SILVA Hernando, Crónicas del cine colombiano, Bogotá, Carlos Valencia Editores, 1981.

SAPIR Micha, “The Impossible Photograph: Hippolyte Bayard's Self-Portrait as a Drowned Man.” In Modern Fiction Studies, 619-629, Baltimore, John Hopkins University Press, 1994.

SEKULA Allan, "On the Invention of Photographic Meaning." In Photography in Print, edited by Vicki Goldberg, 452-473, Albuquerque, University of New Mexico Press, 1981.

SERRANO Eduardo, Historia de la fotografía en Colombia, Bogotá, Museo de Arte Moderno de Bogotá, 1983.

SOBCHACK Vivian, Carnal Thoughts Embodiment and Moving Image Culture, Berkeley, University of California Press, 2004.

SOLOMON-GODEAU Abigail, Photography at the Dock: Essays on Photographic History, Institutions, and Practices, Minneapolis, University of Minnesota Press, 1991. 
SONTAG Susan, Regarding the Pain of Others, New York, Picador, 2004.

TAGG John, The Burden of Representation, Amherst, University of Massachusetts Press, 1988.

von AMELUNXEN Hubertus, "The Century's Memorial-Photography and the Recording of History.", in A New History of Photography, edited by Michel Frizot, 131-146, Köln, Könemann, 1998.

\section{APPENDIXES}

Fig. 1-Lino Lara. El Diez de Febrero, 1906

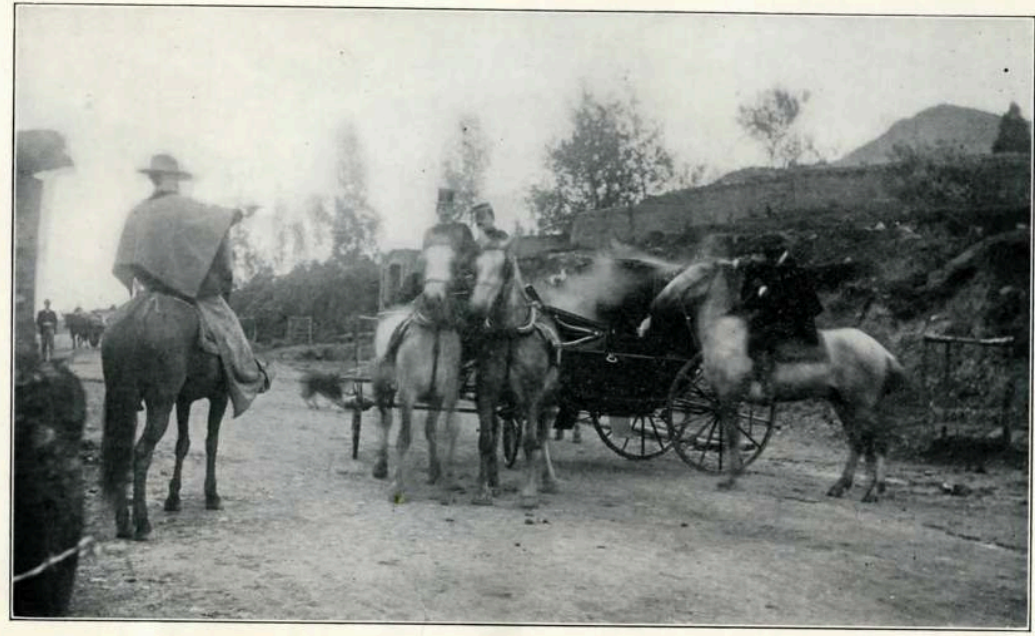

Asalto al Excmo. Sr. Presidente y su hija en "Barrocolorado"

Published in El Diez de Febrero (New York : Imprenta Hispano-Americana, 1907).

Fig. 2-Lino Lara. El Diez de Febrero, 1906.

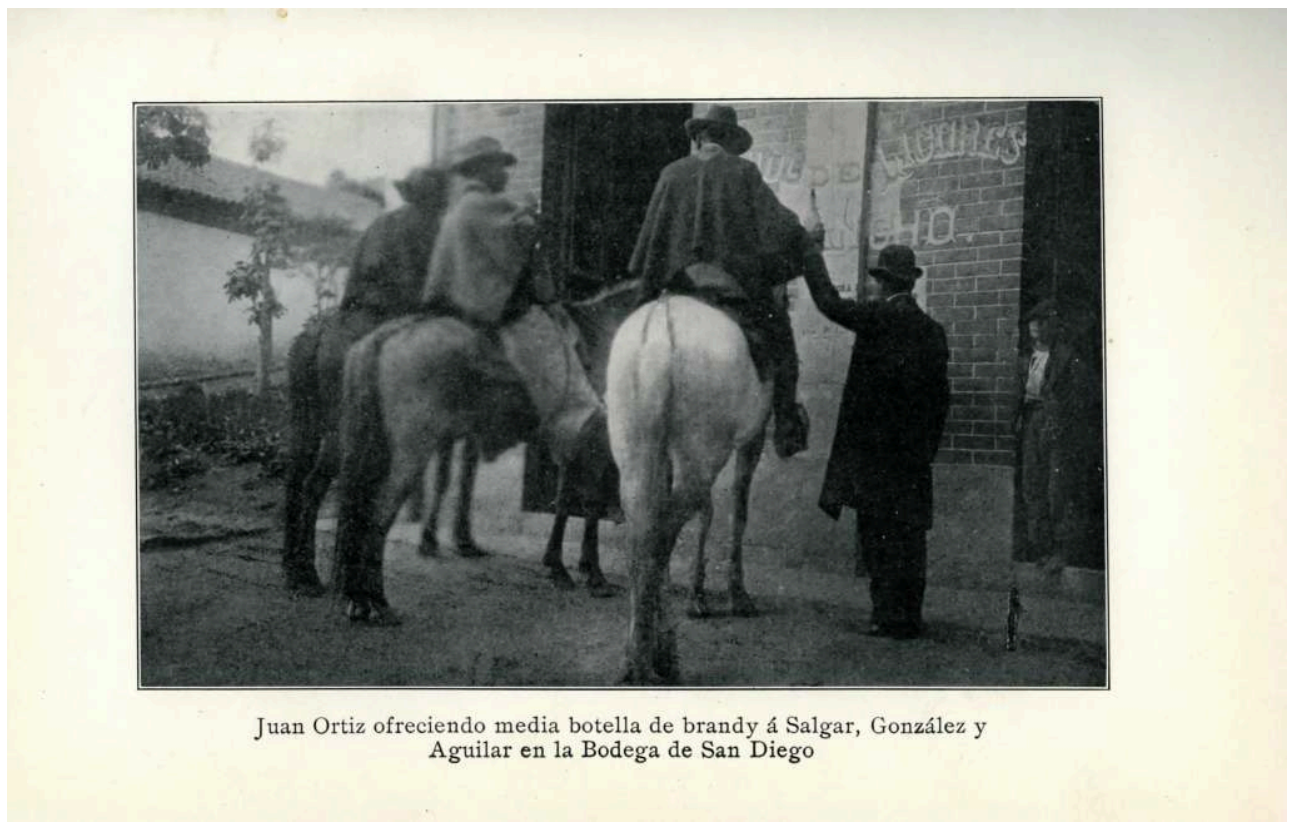


Published in El Diez de Febrero (New York : Imprenta Hispano-Americana, 1907).

Fig. 3-Lino Lara. El Diez de Febrero, 1906.

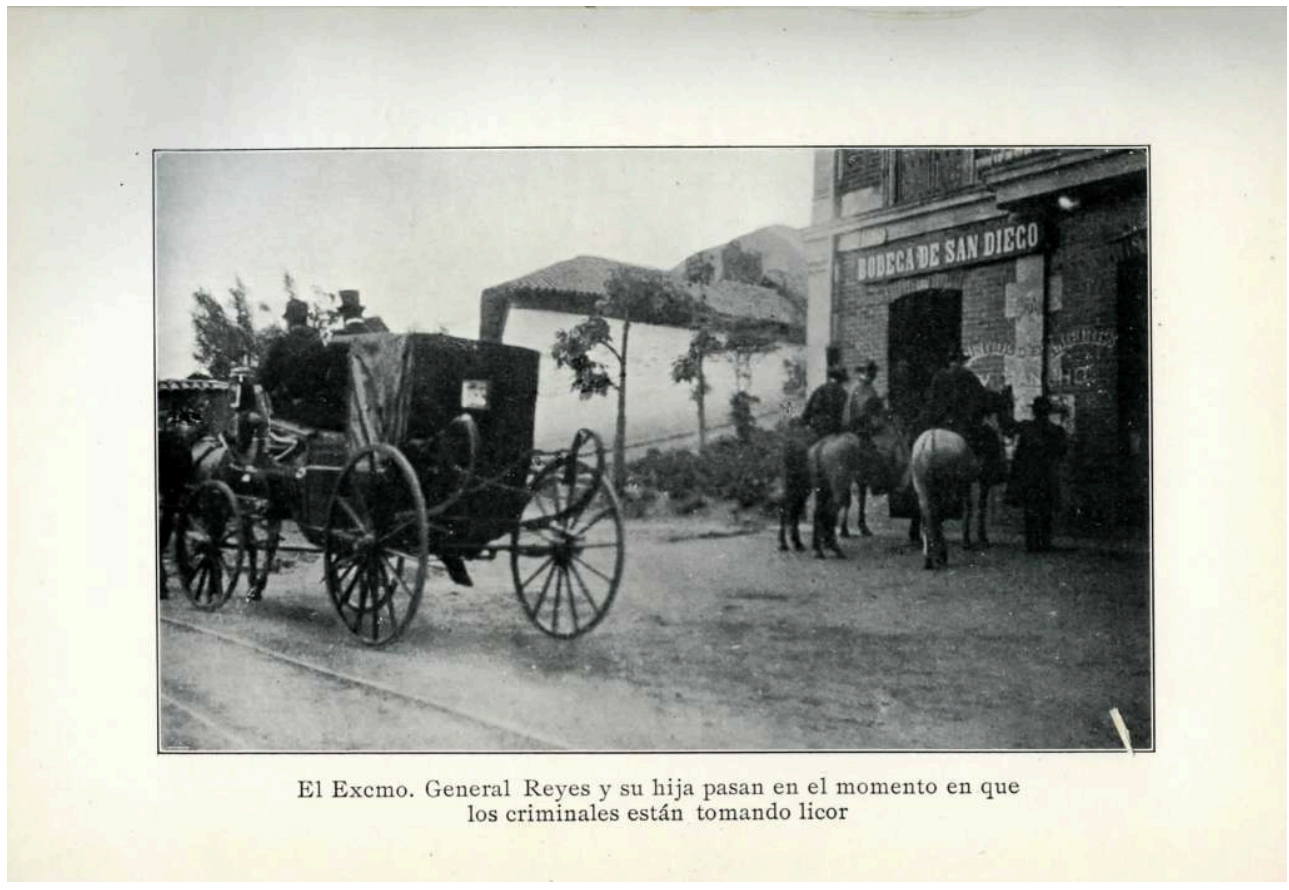

Published in El Diez de Febrero (New York : Imprenta Hispano-Americana, 1907).

Fig. 4-Lino Lara. El Diez de Febrero, 1906.

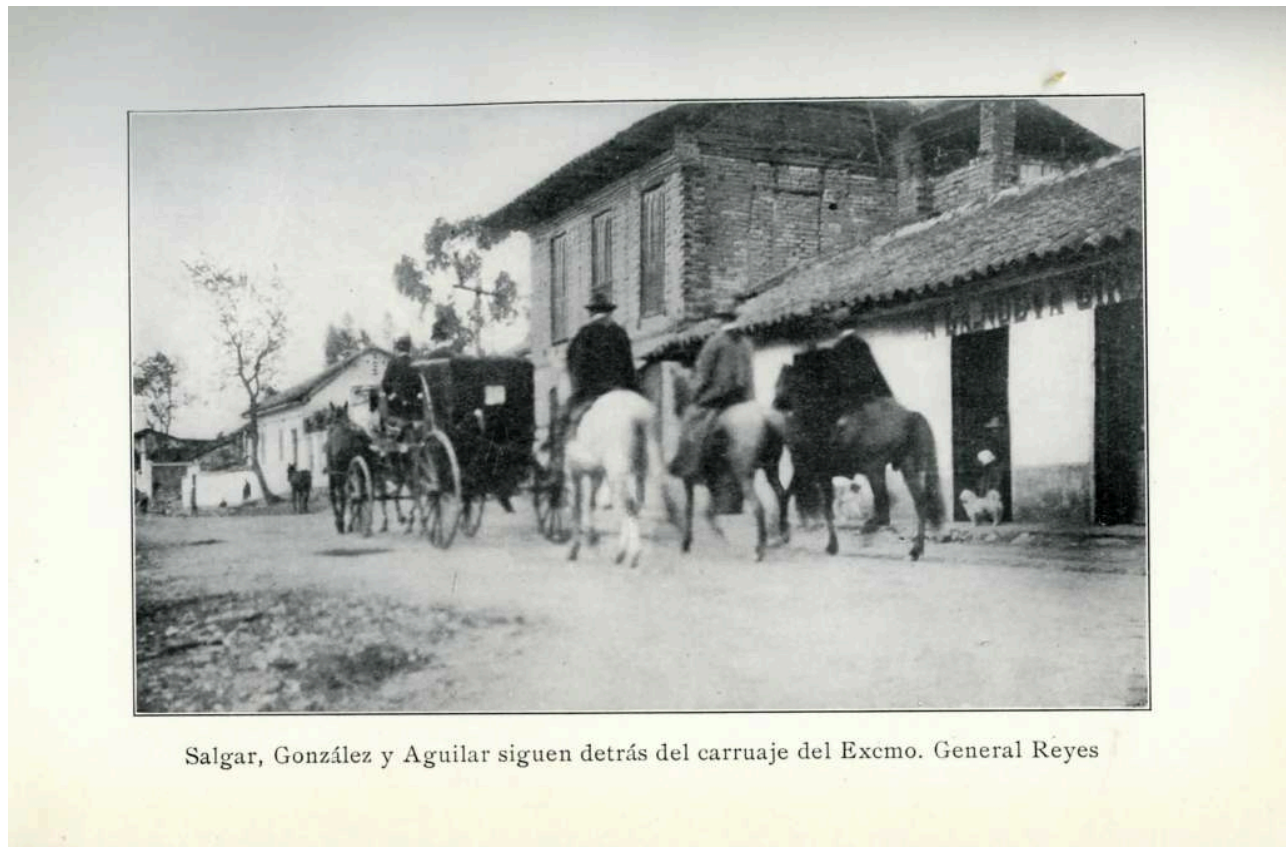

Fig. 5-Lino Lara. El Diez de Febrero, 1906. 


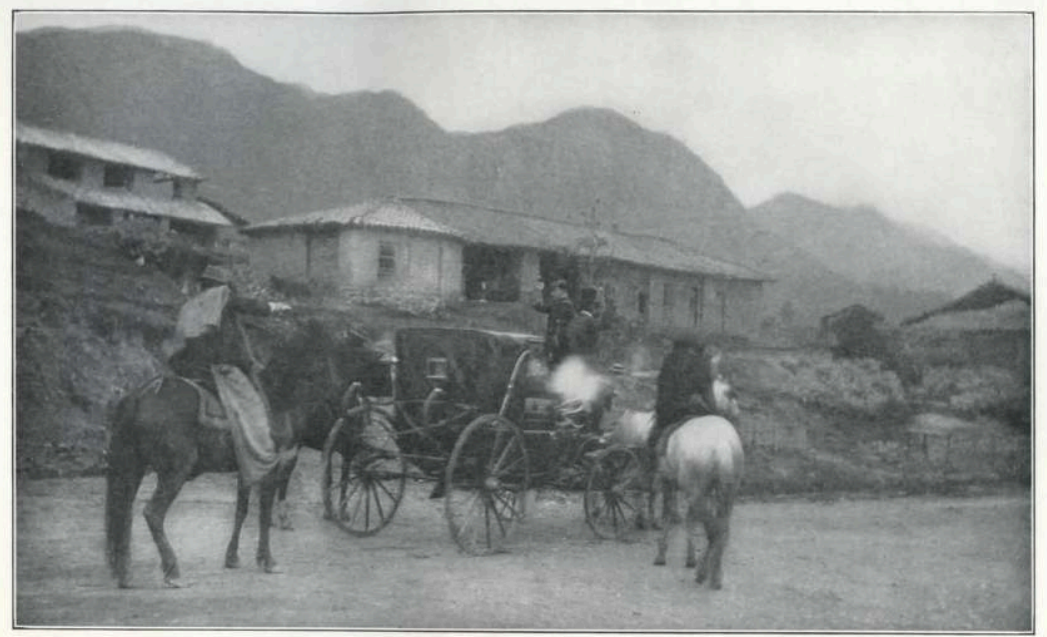

Ataque al Excmo. Sr. Presidente.-E1 Capitán Pomar dispara su revólver

Published in El Diez de Febrero (New York : Imprenta Hispano-Americana, 1907).

Fig. 6-Lino Lara. El Diez de Febrero, 1906.

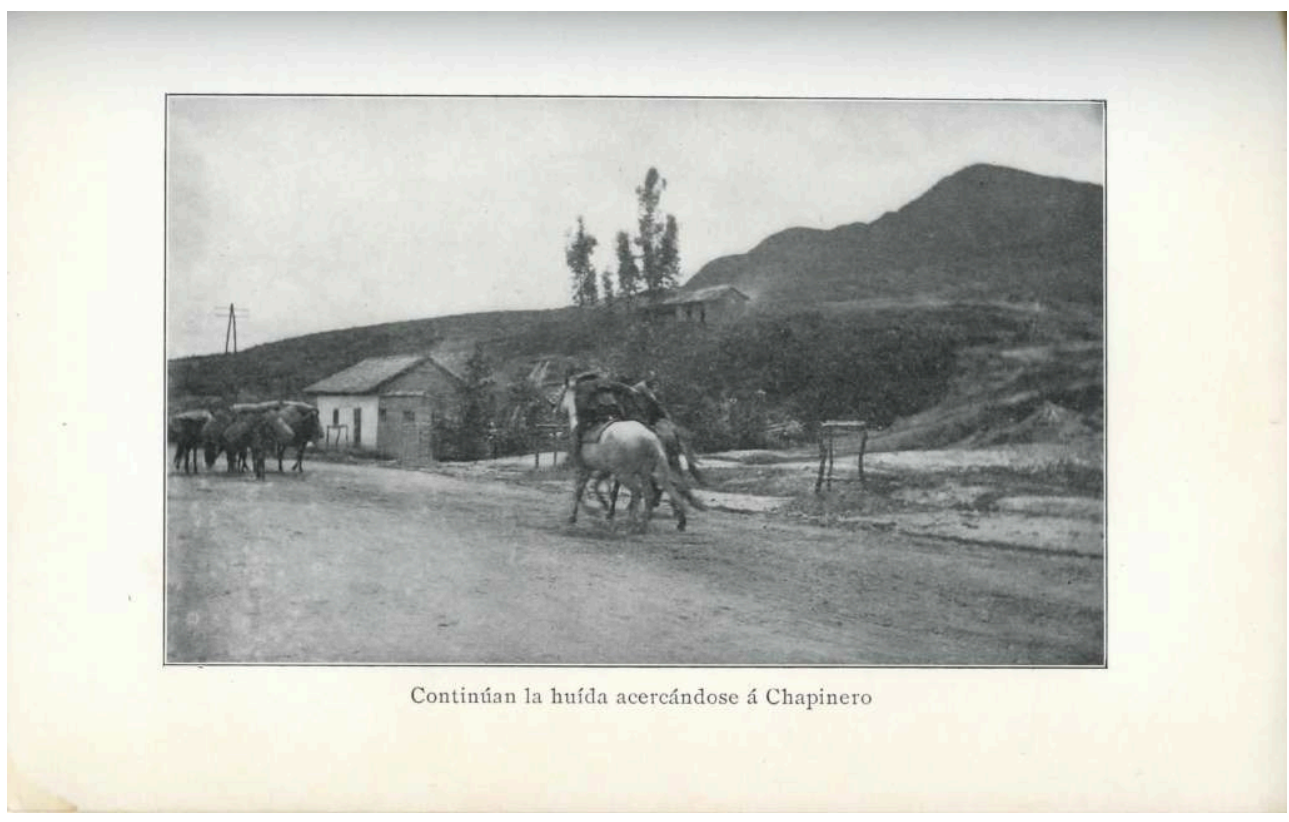

Published in El Diez de Febrero (New York : Imprenta Hispano-Americana, 1907).

Fig. 7-Lino Lara. El Diez de Febrero, 1906. 


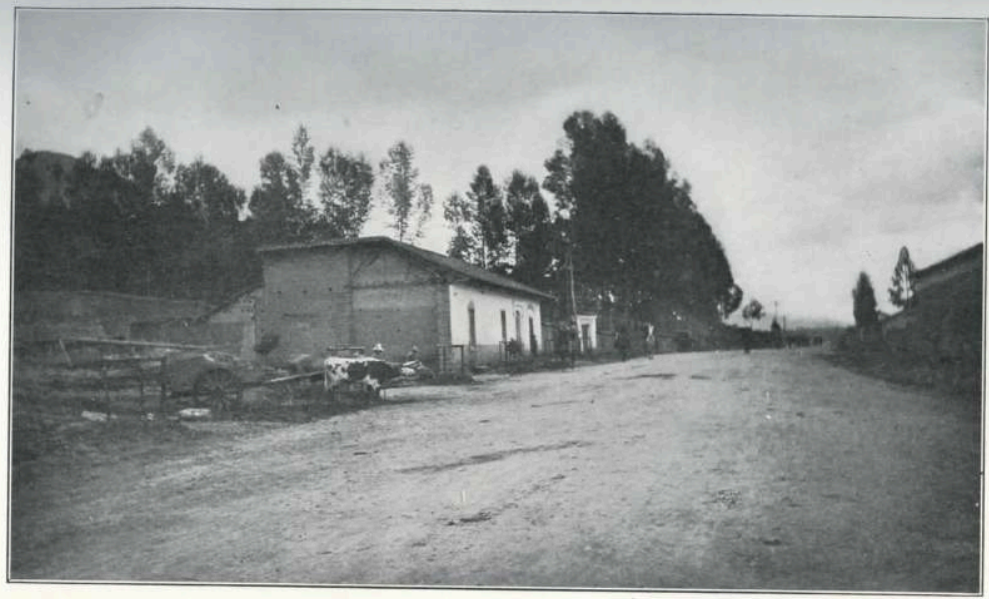

Los tres asaltantes huyen por la carretera del Norte

Published in El Diez de Febrero (New York : Imprenta Hispano-Americana, 1907).

Fig. 8-Lino Lara. El Diez de Febrero, 1906.

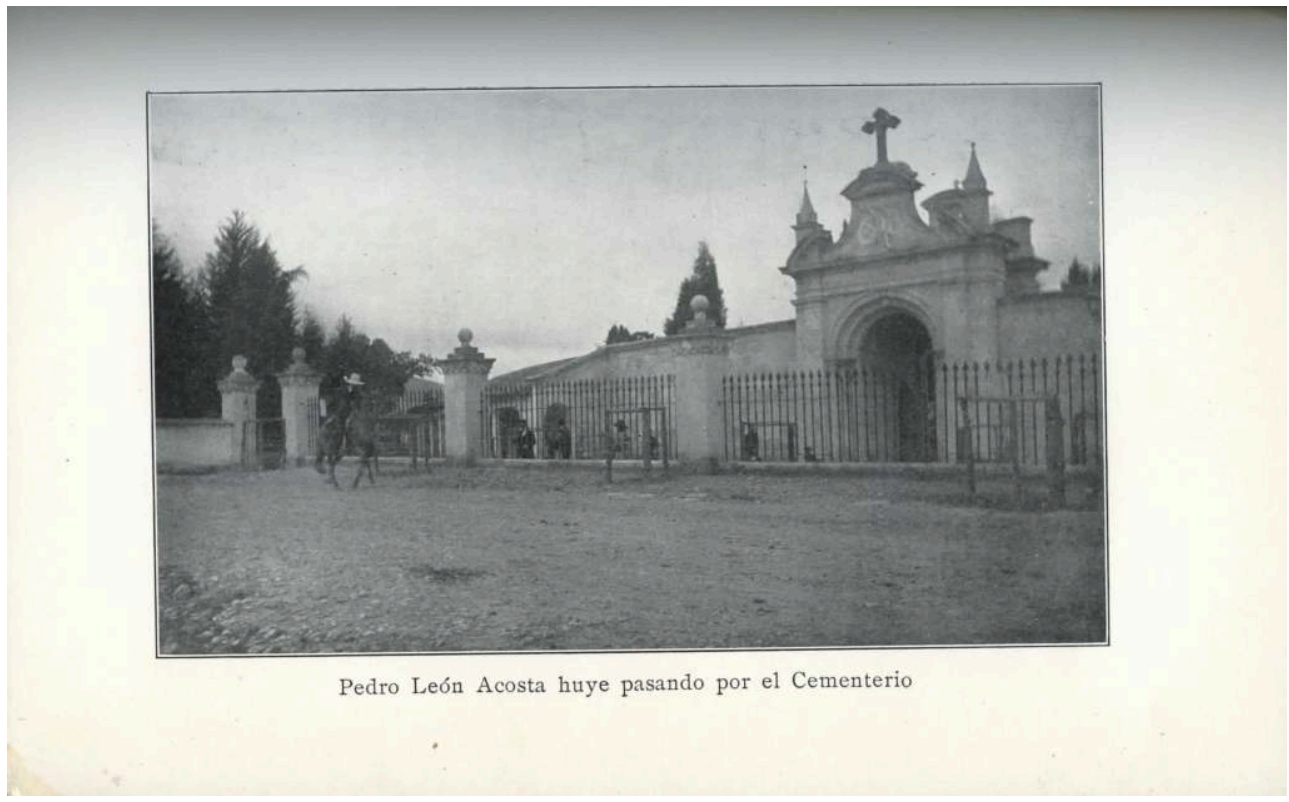

Published in El Diez de Febrero (New York : Imprenta Hispano-Americana, 1907).

Fig. 9-Lino Lara. El Diez de Febrero, 1906. 


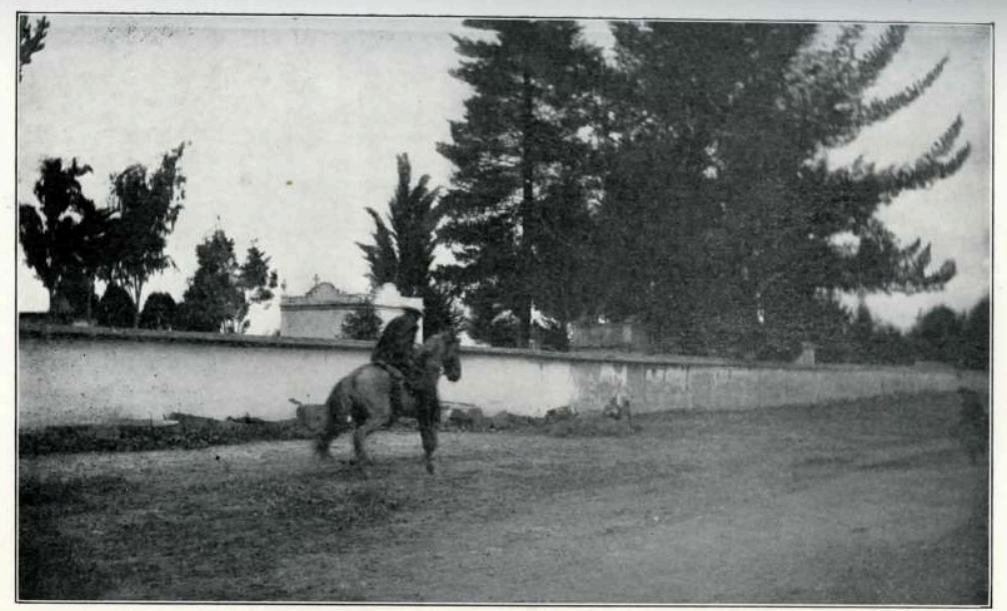

Pedro León Acosta huye camino del Salitre

Published in El Diez de Febrero (New York : Imprenta Hispano-Americana, 1907).

Fig. 10-Lino Lara. El Diez de Febrero, 1906.

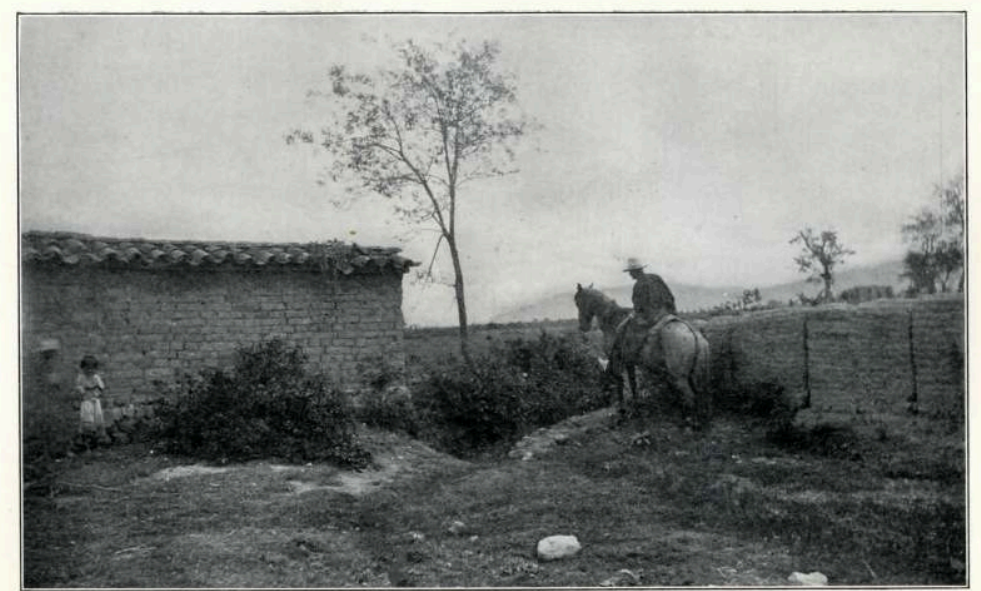

Pedro León Acosta hace saltar á su caballo una zanja en el Salitre

Published in El Diez de Febrero (New York : Imprenta Hispano-Americana, 1907).

Fig. 11-Lino Lara. El Diez de Febrero, 1906. 


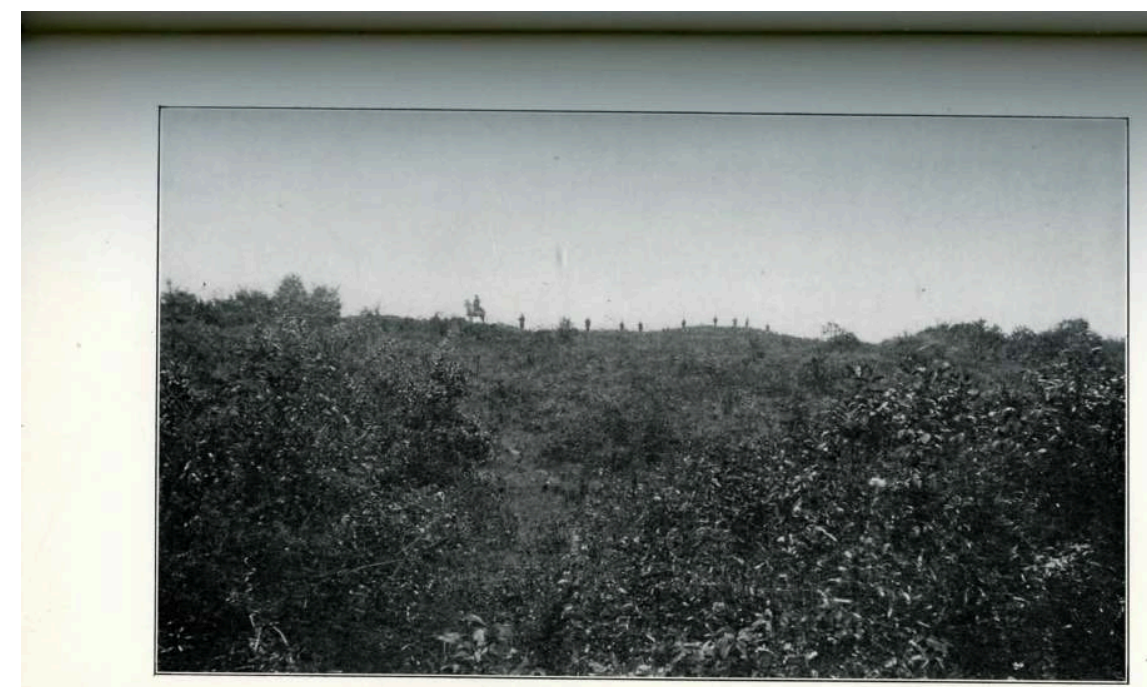

E1 General Pedraza y la Policía bajan la cuchilla de Suba

Published in El Diez de Febrero (New York : Imprenta Hispano-Americana, 1907).

Fig. 12-Lino Lara. El Diez de Febrero, 1906.

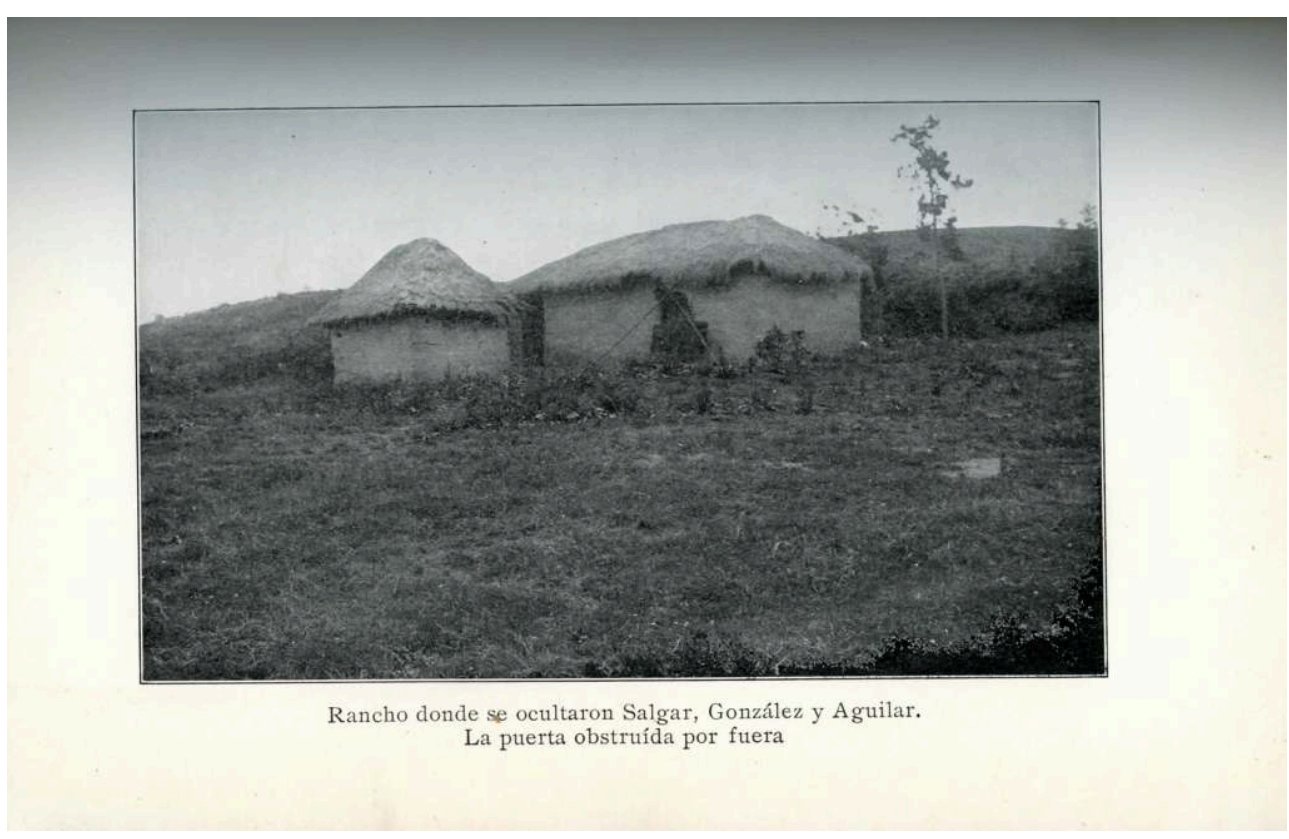

Published in El Diez de Febrero (New York : Imprenta Hispano-Americana, 1907).

Fig. 13-Lino Lara. El Diez de Febrero, 1906. 


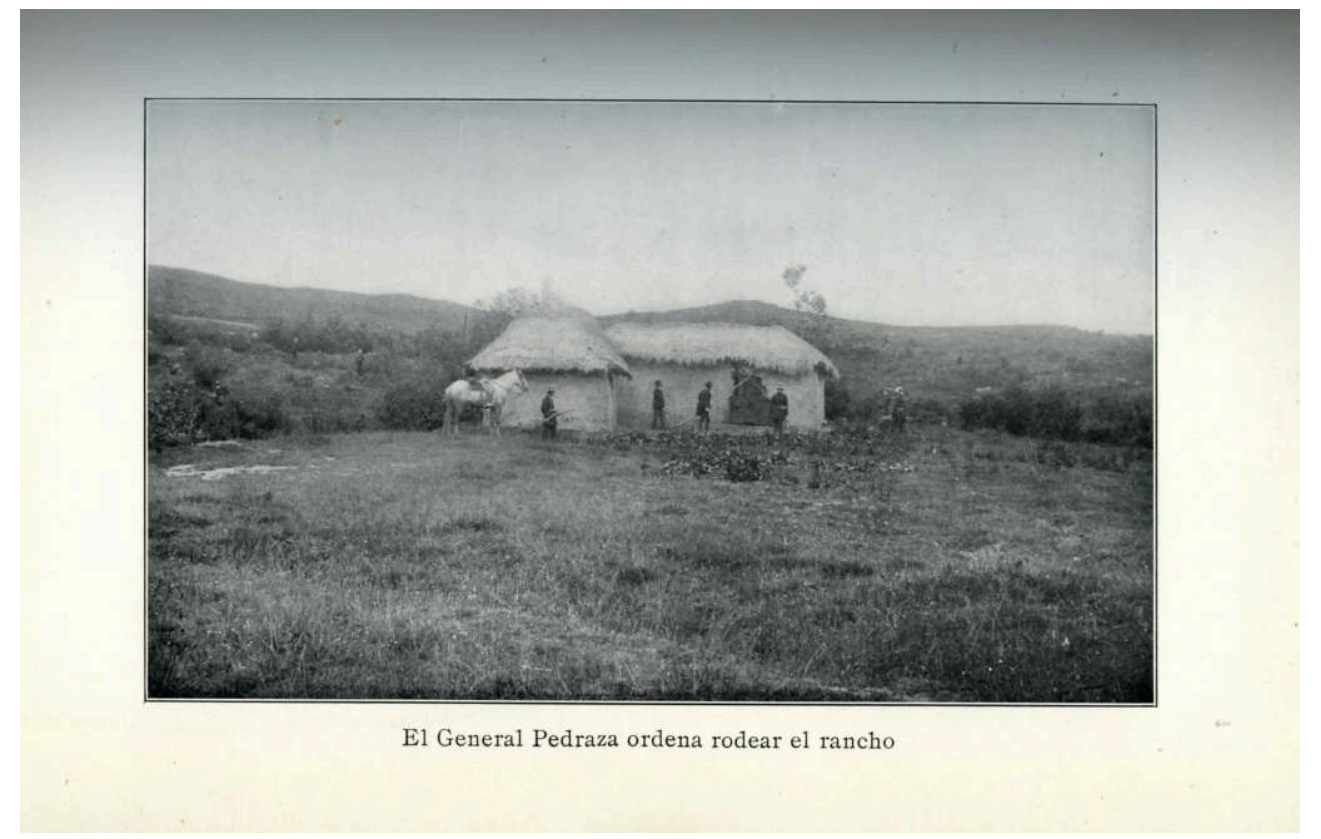

Published in El Diez de Febrero (New York : Imprenta Hispano-Americana, 1907).

Fig. 14-Lino Lara. El Diez de Febrero, 1906

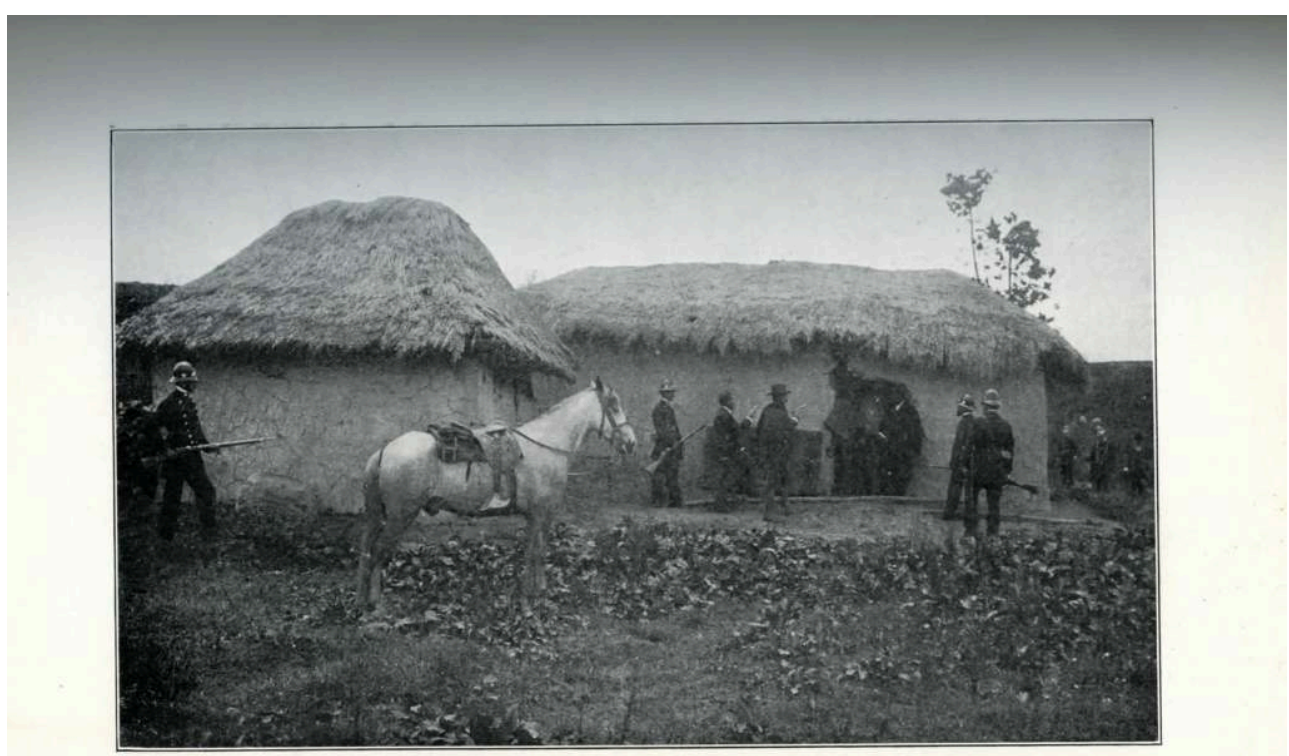

E1 General Pedraza, revólver en mano, intima prisión á los criminales

Published in El Diez de Febrero (New York : Imprenta Hispano-Americana, 1907).

Fig. 15-Lino Lara. El Diez de Febrero, 1906. 


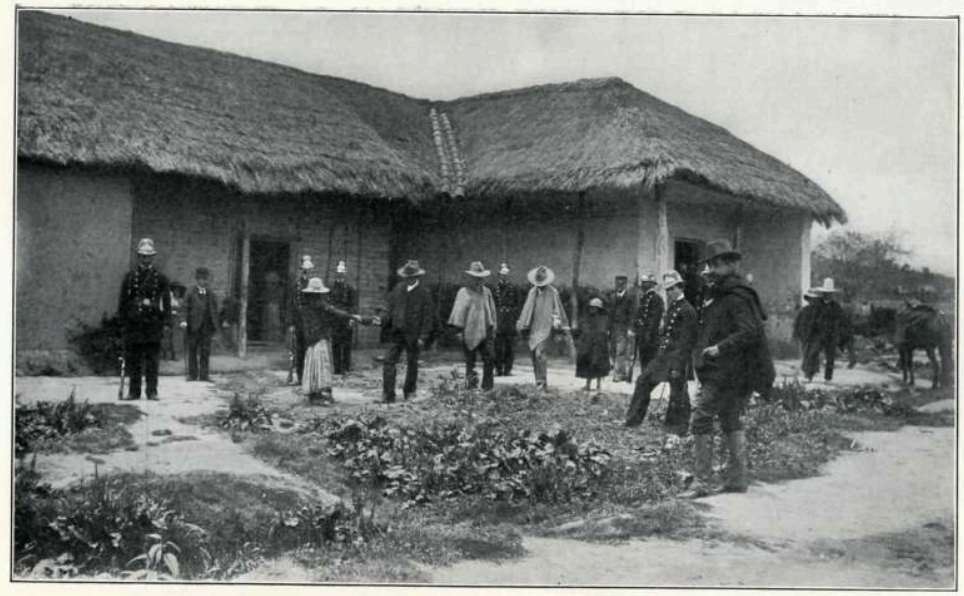

Se permite á los criminales tomar alimentos en una venta del camino de Suba

Published in El Diez de Febrero (New York : Imprenta Hispano-Americana, 1907).

Fig. 16-Lino Lara. El Diez de Febrero, 1906.

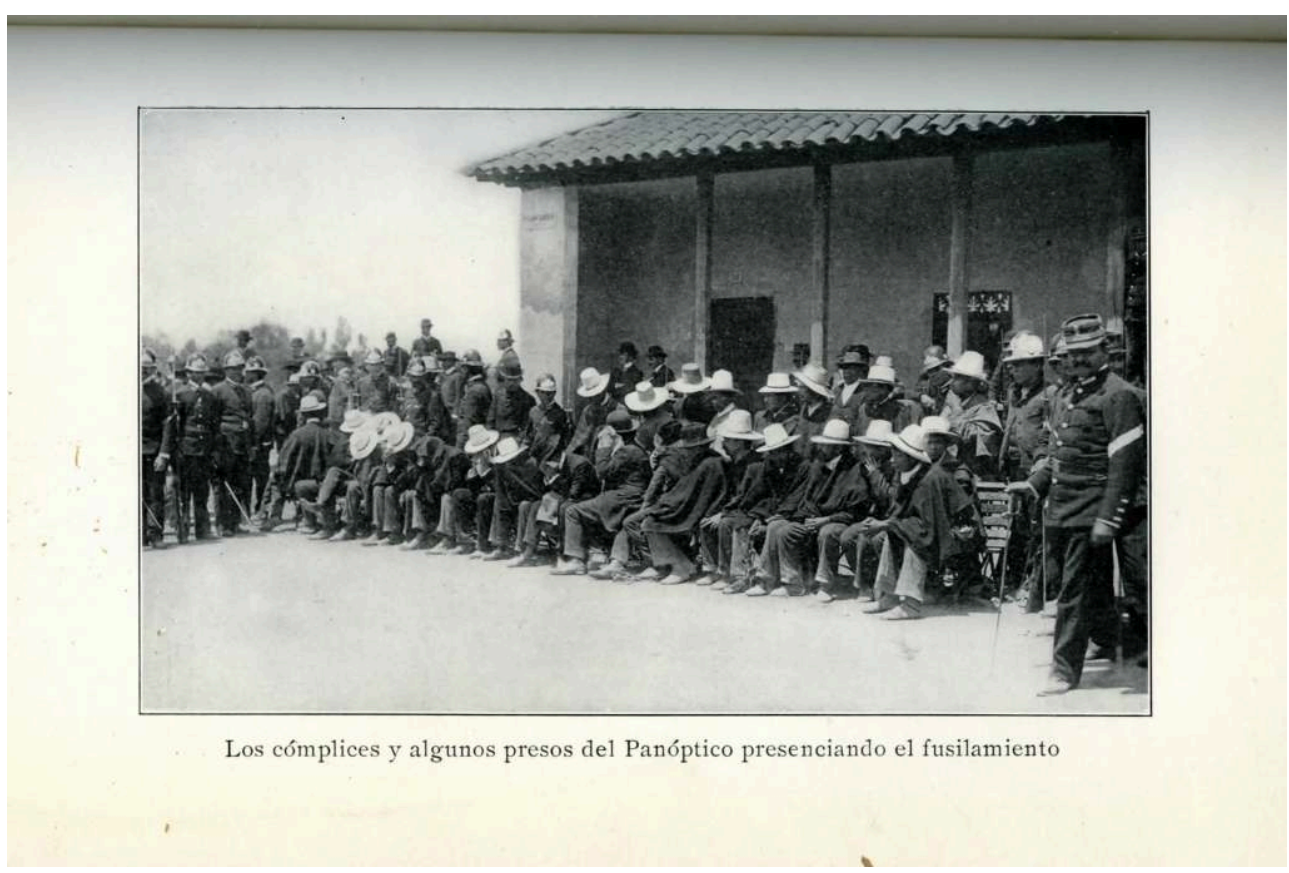

Published in El Diez de Febrero (New York : Imprenta Hispano-Americana, 1907).

Fig. 17. Lino Lara. El Diez de Febrero, 1906. 


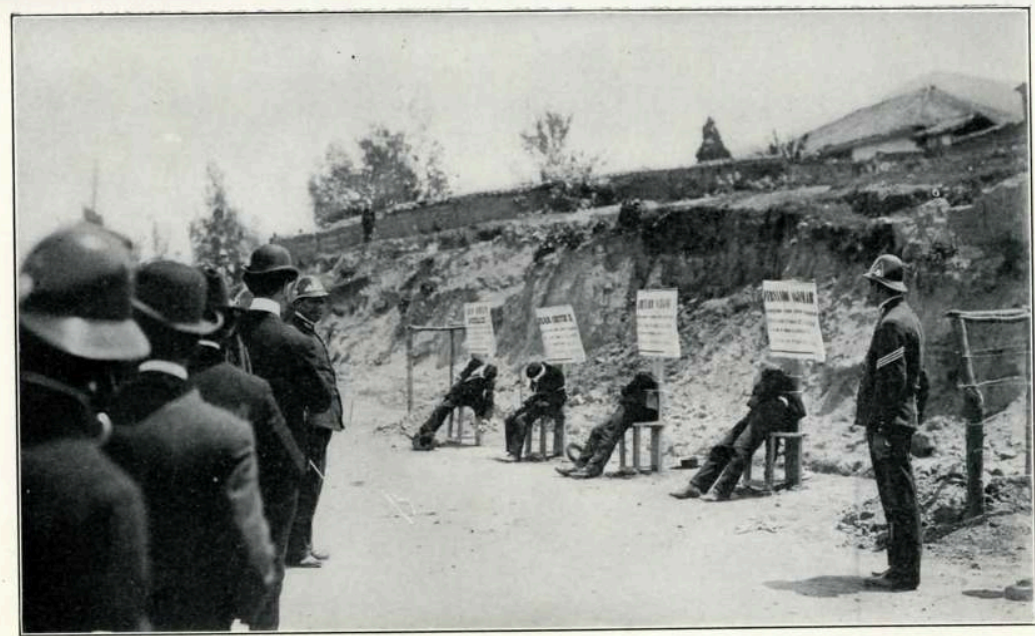

Después de la descarga

Published in El Diez de Febrero (New York : Imprenta Hispano-Americana, 1907).

Fig. 18. Lino Lara. El Diez de Febrero, 1906.

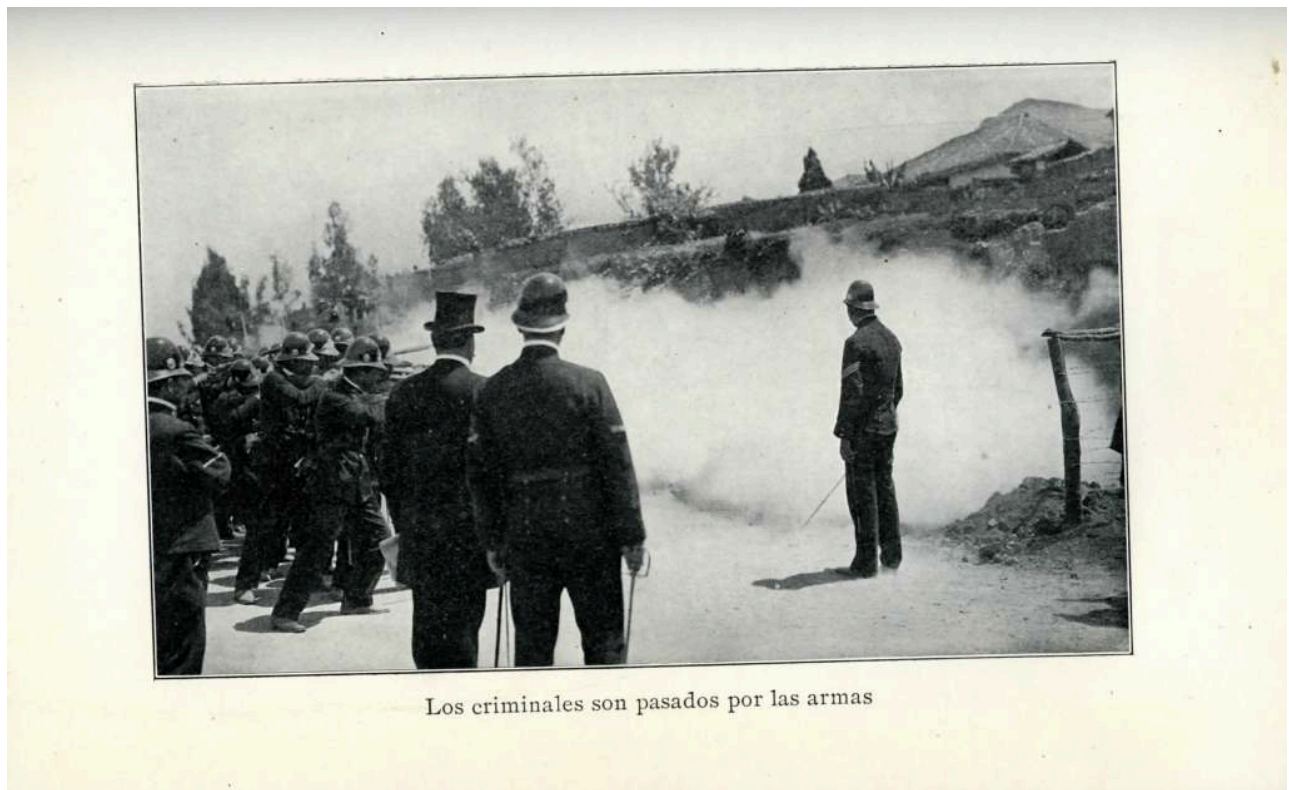

Published in El Diez de Febrero (New York : Imprenta Hispano-Americana, 1907).

Fig. 19. Lino Lara. El Diez de Febrero, 1906. 


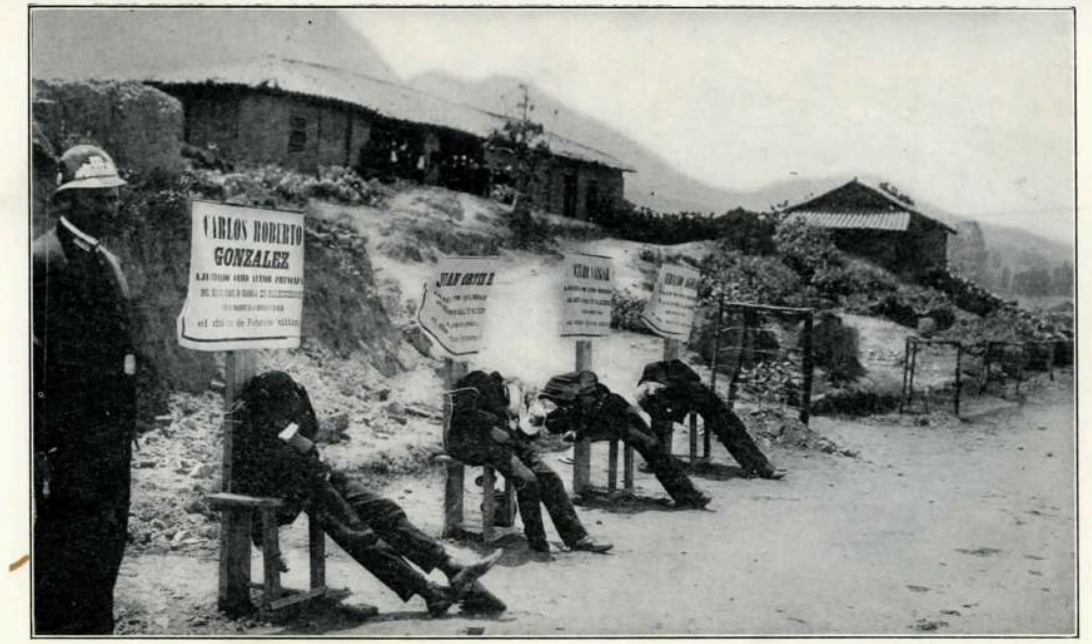

Segunda descarga

Published in El Diez de Febrero (New York : Imprenta Hispano-Americana, 1907).

Fig. 20. Lino Lara. El Diez de Febrero, 1906.

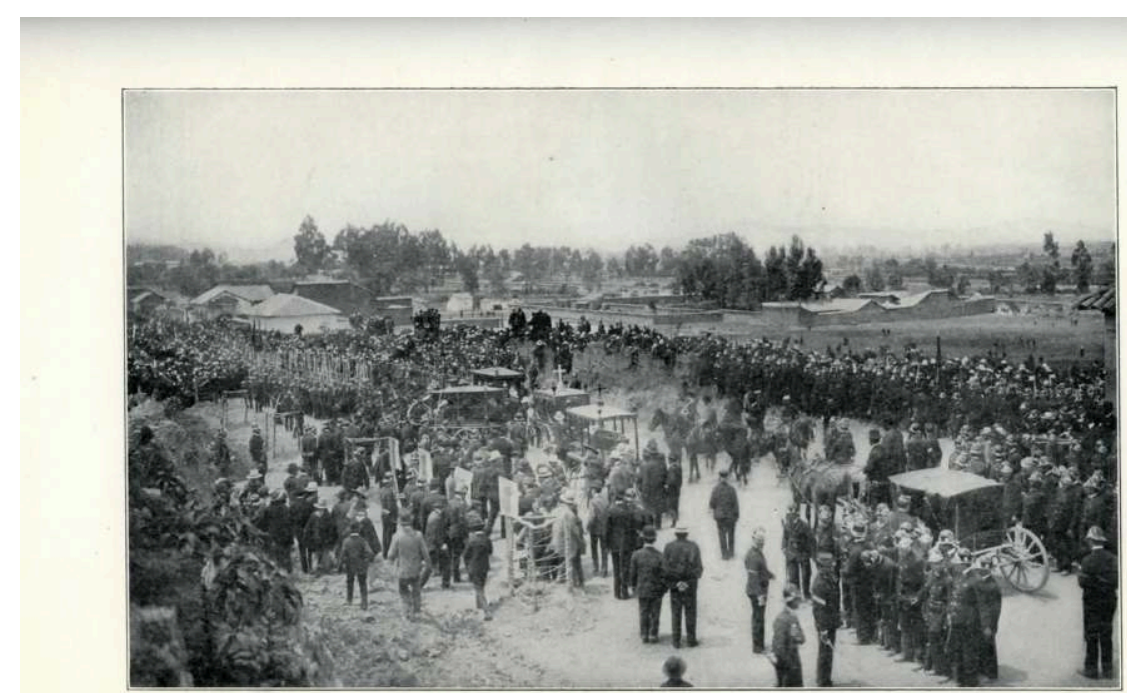

Los cadáveres son conducidos al cementerio

Published in El Diez de Febrero (New York : Imprenta Hispano-Americana, 1907).

Fig. 21- Ernest Eugène Appert. Crimes de la Commune - Execution des otages, prison de la Roquette 


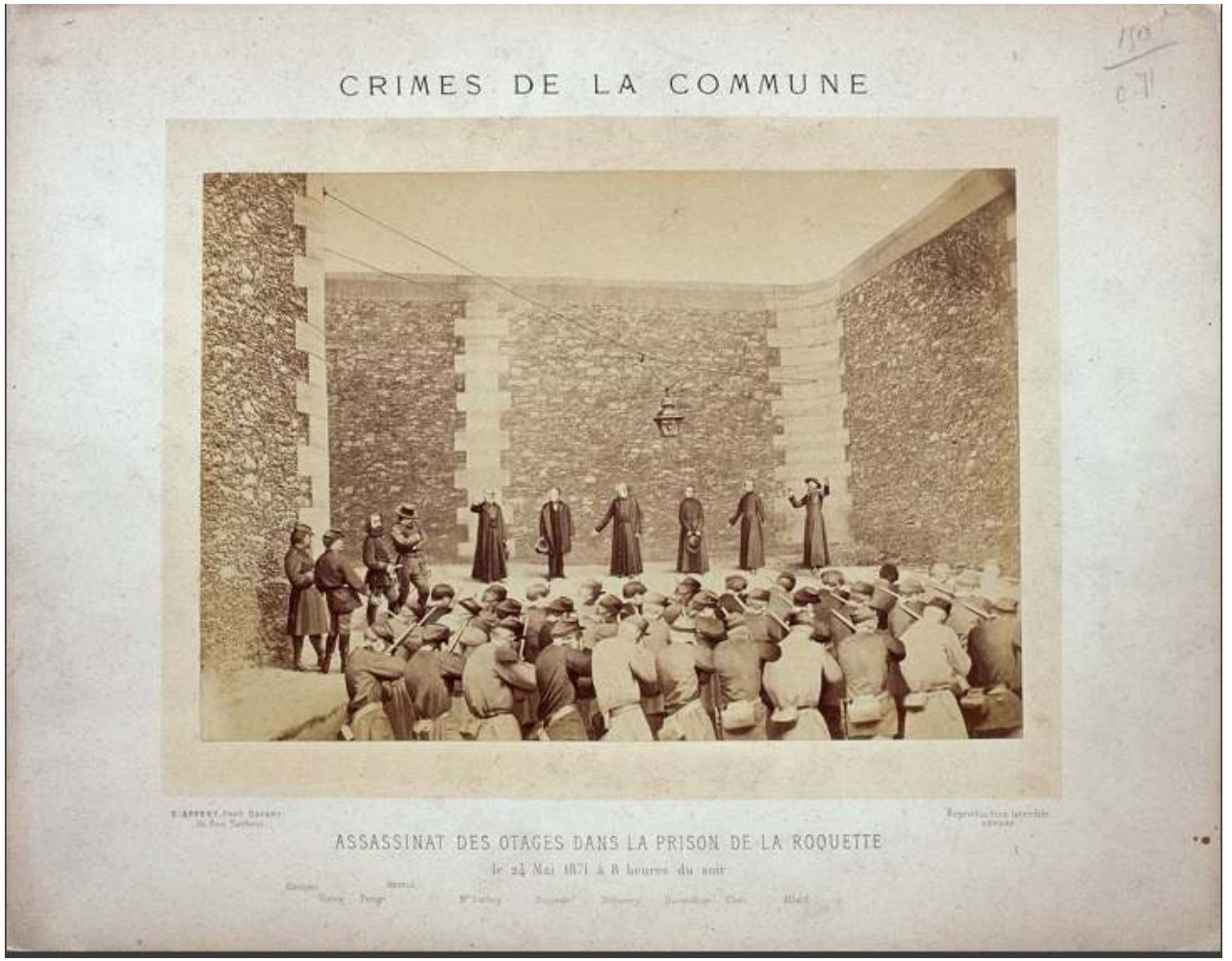

Albumen silver print from glass negative. Metropolitan Museum of Art (2012.352 (10)), le 24 mai, 1871.

Fig. 22- Ernest Eugène Appert. Crimes de la Commune - Execution of Generals Clément Thomas and Jules Lecompte,... March 18, 1871, 1871.

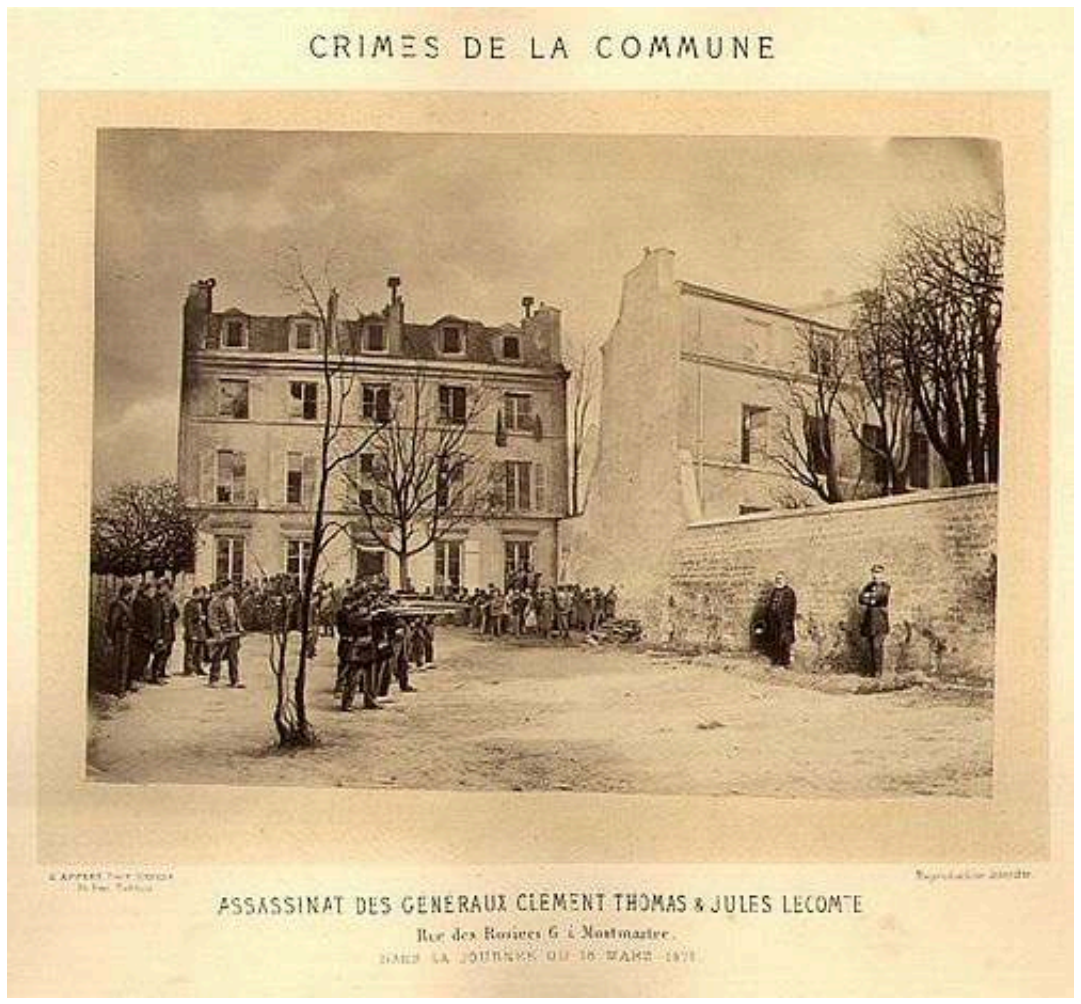


Albumen silver print from glass negative. Det Kongelige Bibliotek, (The Royal Library, Copenhagen, Denmark - http://www.kb.dk/)

\section{NOTES}

1. Rafael Reyes had a strong power ambition and an authoritative character. When he came into power Reyes convened a national assembly that replaces the Congress and suppresses the vicepresidency. For more information see David Bushnell, Colombia una nación a pesar de si misma: de los tiempos precolombinos a nuestros días (Bogotá : Planeta, 1997).

\section{ABSTRACTS}

In 1907 the anonymous book El 10 the Febrero started to circulate in Colombia. The book compiled the documentation -including photographs-of the attempted assassination of Colombia's current president Rafael Reyes and the subsequent public execution by firing squad of the conspirators. It is well known today that the photographs of the assassination attempt were staged and that the execution images were taken during the actual event. However, the publication makes no difference between the images, treating them as equally valid, and therefore investing the staged images with a sense of facticity that otherwise they would lack. Through the concept of translation, this text will look into the ways in which veracity is invested from one image to another and how through this process, the anonymous author (now considered to be the president himself) takes advantage of photography's capacity to depict reality as such.

En 1907, le livre anonyme El 10 de la Febrero commençait à circuler en Colombie. Le livre compilait la documentation - comprenant des photos - de la tentative d'assassinat du président colombien Rafael Reyes et l'exécution publique qui suivi par un peloton d'exécution de conspirateurs. Il est bien connu aujourd'hui que les photographies de la tentative d'assassinat ont été organisées et que les images d'exécution ont été prises lors de l'événement réel. Toutefois, la publication ne fait aucune différence entre les images, les traitant de la même manière, et utilise ainsi les images mises en scène avec la realité qui il leur manquait. A travers le concept de traduction, ce texte se penchera sur la façon dont la véracité est utilisée d'une image à l'autre et comment, grâce à ce processus, l'auteur anonyme (aujourd'hui considéré comme le président lui-même, a tenté d'obtenir l'appui de l'exécution des 'conspirateurs') tire profit de la capacité de la photographie à représenter la réalité.

\section{AUTHOR}

\section{JUANITA SOLANO ROA}

PhD Candidate, Institute of Fine Arts, NYU History of Latin American Art and History of Photography juanitasolano[at]gmail.com 